\title{
Editorial
}

\section{Clinical governance: a statutory duty for quality improvement}

A frequently aired concern of health professionals throughout the world is the extent to which financial issues dominate the health care agenda. If most of the time of the senior management of health care organisations is directed towards finance, it is argued, how can a commitment towards quality be anything other than rhetoric?

Since the beginning of the present decade, the British National Health Service (NHS) has operated as an internal market. ${ }^{1}$ In it, the forces and incentives of a market were seen as creating an environment within a public sector, nonprofit making system that would yield greater efficiency and improved quality. The new Labour Government that came to power in the spring of 1997 brought to an end this ethos for the health care system in Britain. Many had come to see it as engendering division and rivalry between hospitals, which, far from promoting efficiency, had encouraged duplication, overcapacity and had slowed down badly needed rationalisation of services. In publishing a white paper ${ }^{2}$ that seeks to dismantle this internal market and to replace competition with collaboration, the Government has also given an important new status to quality. By creating a statutory duty for quality, through "clinical governance" at local level, the NHS is seeking to create a new rigour and accountability for the standard of care provided to patients in hospitals and in primary care.

The term clinical governance introduced in the white paper resonates with that of corporate governance, a set of financial duties, accountabilities, and rules of conduct that were recommended ${ }^{3}$ for private sector companies in the aftermath of a number of high profile misdemeanours in the financial markets of the City of London. Later, formal corporate governance policies also became a requirement for health care organisations in Britain. ${ }^{4}$ A commitment to good corporate governance brings with it the certainty that financial issues will be taken very seriously and will assume a central role in the business of the boards of directors that govern hospitals and other health care institutions.

Responsibility for quality in healthcare has developed along a more informal route. Hospitals and other organisations have increasingly had to meet specific targets (for example in relation to patient response times ${ }^{5}$ ) for quality improvement but accountability within this field of healthcare has sometimes seemed fragmented. While the management of many public sector bodies in the 1990s has sought to embrace organisation wide quality improve- ment strategies-such as total quality management ${ }^{6}$ - which have been so important to the success of the world's leading manufacturing and service industries, professionally based approaches to quality have also been developing. Notably, the evidence-based medicine movement ${ }^{7}$ has rapidly become international in its scope as doctors and other health care professionals have recognised that a failure to make day to day use of the lessons of research was producing wasteful variation in clinical decision making and unacceptable departures from best practice.

Specialist electronic data bases, greater access to information through the internet, reorientation of traditional medical libraries, training in critical appraisal skills, clinical practice guidelines, and computerised clinical decision-support systems are only part of a new infrastructure that health care organisations must put in place if they are to give proper support to the development of evidence-based practice at local level. The multi-faceted nature of these changes is posing a particular challenge for the leaders of health care organisations who must comprehend how they fit together to comprise an integrated quality strategy. ${ }^{8}$

Set alongside this lack of clarity in a complex and developing field, are traditional barriers between managerial and professional approaches to quality. For example, clinical audit can be portrayed by the professionals as their exclusive domain with an emphasis on educational approaches to change and improvement. Managers often perceive it as a secretive activity that does not yield tangible benefits for the organisation. The obstacles to moving forward, therefore, are probably much more attitudinal than conceptual as models of integrating continuous quality improvement programmes are not complicated. ${ }^{9}{ }^{10}$

Despite the enthusiasm and commitment to quality improvement by health services and health professionals over the past decade, public confidence is still very susceptible to media coverage of problems in the delivery of health services. Thus, reports of inquiries into lapses in standards of care in particular hospitals often recount a catalogue of failures in management and clinical leadership as well as errant individual behaviour. Worse still is the enormously negative public impact of recurrences of similar failures, giving an impression that health services are unable to correct problems reliably and conveying a sense of history repeating itself. The issue of poor professional 
practice and the so called "problem doctor"11 has also come to prominence in recent years and is a further source of public disquiet about the quality of healthcare. Although this has led to strengthening of the professional regulatory machinery in Britain, ${ }^{12}$ there is still a need for the prevention, early detection and resolution of such problems at local level. ${ }^{13}$

The new duty for clinical governance in the local NHS will tackle these quality issues. It is envisaged that there will be an "accountable officer" in each hospital and other healthcare organisations, that boards will receive monthly reports, and that annual reports will be made available to the public. The clinical governance role will be wide ranging and include ensuring that: quality improvement processes are in place and integrated with the quality programme for the organisation as a whole; that evidence-based practice is in day to day use with the infrastructure to support it; that good practice ideas and innovations are systematically disseminated and applied; that poor clinical performance is promptly recognised and dealt with to prevent harm to patients; and, that the quality of data collected to monitor clinical care is itself of a high standard. ${ }^{2}$ Two new external quality bodies will help to facilitate and reinforce this local duty: a National Institute for Clinical Excellence and a Commission for Health Improvement.

In seeking a fundamental redefinition of the duties and accountability of public sector bod- ies in Britain, the new Labour Government is in harmony with the task of rethinking the role of the state the world over. ${ }^{14}$ Its white paper ${ }^{2}$ seeks to create a new National Health Service that can command the confidence of the public that it serves. Clinical governance is a big idea that deserves to take central stage in the quest for high standards in the quality of healthcare.

\section{LIAM J DONALDSON}

NHS Executive: Northern and Yorkshire Regional Office, John Snow House, Durham University Science Park, Durham, DH1 $3 Y$ G

1 Working for patients. London: HMSO, 1989.

2 The new NHS: modern and dependable. London: HMSO, 1997.

3 Report of the Committee on the Financial Aspects of Corporate Governance. London: Gee and Co, 1992.

4 Committee on Standards in Public Life. Report of the Committee on Standards in Public Life. London: HMSO, 1995.

5 Secretary of State for Health. The patient's charter: raising the standard. London: HMSO, 1991.

6 Deming WE. Out of the crisis. Cambridge: Cambridge University Press, 1986.

7 Evidence-based Medicine Work Group. Evidence-based medicine: a new approach to teaching the practice of medimedicine: a new approach to te.

8 Donaldson LJ. Impact of management on outcomes. In: Peckham M, Smith R, eds. Scientific basis of health services. London: BMJ Publishing Group, 1986.

9 Berwick DM. Continuous improvement as an ideal in Berwick DM. Continuous improvement as
healthcare. $N$ Engl f Med 1982; 307:343-7.

10 Dealthcare. N Engl f Med 1982;307:343-7. Donaldson LJ, Thomson RG. Medical audit and the
quality debate. F Public Health Med 1990;12:149-51.

11 Donaldson LJ. Doctors with problems in an NHS workforce. $B M \mathcal{F} 1994 ; 308: 1277-82$.

2 General Medical Council. The new performance procedures: consultative document. London: GMC, 1997.

13 Donaldson LJ. Doctors with problems in a hospital workforce. In: Lens P, Wal G van der, eds. Problem doctors: $a$ conspiracy of silence. Amsterdam: 10S Press, 1997.

14 World Bank. World Development Report: The state in a changing world. Oxford: Oxford University Press, 1997. 